\title{
Air pollution and the skin
}

\section{Eleni Drakaki, Clio Dessinioti and Christina V. Antoniou*}

Photobiology Unit, First Department of Dermatology, School of Medicine, Andreas Sygros Hospital, University of Athens, Athens, Greece

Edited by:

Daniele Bortoli, University of Evora, Portugal

\section{Reviewed by:}

Charitomeni Vavouli, Andreas

Sygros University Hospital, Greece

Margherita Premuda, Institute of

Atmospheric Sciences and Climate

(CNR-ISAC), Italy

\section{*Correspondence:}

Christina V. Antoniou, First

Department of Dermatology, School

of Medicine, "Andreas Sygros"

Hospital, University of Athens, 51.

Dragoumi Street, Athens 16121,

Greece

e-mail: christinaantoniougr@

yahoo.com
The increase of air pollution over the years has major effects on the human skin. The skin is exposed to ultraviolet radiation (UVR) and environmental air pollutants such as polycyclic aromatic hydrocarbons (PAHs), volatile organic compounds (VOCs), oxides, particulate matter (PM), ozone $\left(\mathrm{O}_{3}\right)$, and cigarette smoke. Although human skin acts as a biological shield against pro-oxidative chemical and physical air pollutants, the prolonged or repetitive exposure to high levels of these pollutants may have profound negative effects on the skin. Exposure of the skin to air pollutants has been associated with skin aging and inflammatory or allergic skin conditions such as atopic dermatitis, eczema, psoriasis or acne, while skin cancer is among the most serious effects. On the other hand, some air pollutants (i.e., $\mathrm{O}_{3}$, nitrogen dioxide, and sulfur dioxide) and scattering particulates (clouds and soot) in the troposphere reduce the effects of shorter wavelength UVR and significant reductions in UV irradiance have been observed in polluted urban areas.

Keywords: air pollution, ultraviolet radiation, particulate matter, polycyclic aromatic hydrocarbons, volatile organic compounds, ozone, skin, aging

\section{INTRODUCTION}

The human skin, and mainly the upper layer of the epidermis, plays the role of a barrier, but is also one of the first and major targets of air pollutants. Air pollutants include those of environmental origin, as well as those of anthropic origin (Valacchi et al., 2012). Major air pollutants with effects on the skin include the solar ultraviolet radiation (UVR), polycyclic aromatic hydrocarbons (PAHs), volatile organic compounds (VOCs), nitrogen oxides (NOx), particulate matter (PM), and cigarette smoke. The actions of various air pollutants may be amplified in the presence of other air pollutants and with the interaction of UVR, and form major active components of the pro-oxidant smog (Baudouin et al., 2002; Katsouyanni, 2003; Kampa and Castanas, 2008).

Depending on the nature of these pollutants and the integrity of the skin, the modes of the penetration of pollutants differ. Alterations that disturb the skin barrier function, in either stratum corneum lipid metabolism or protein components of the corneocytes, are involved in the development of various skin diseases. The protective ability of the skin is not unlimited, and problems arise when an abnormal exposure to environmental stressors exceeds the skin's normal defensive potential (Valacchi et al., 2012).

Air pollutants may induce severe interference of normal functions of lipids, DNA and/or proteins of the human skin via oxidative damage (Adelman et al., 1988; Karten et al., 1988; Halliwell and Gutteridge, 1989; Stadtman, 1992; Gaboran et al., 1993; Menzel, 1994; Ames et al., 1995; Valko et al., 2006; Kampa and Castanas, 2008), leading to skin aging, inflammatory or allergic conditions such as atopic dermatitis, psoriasis and acne, and skin cancer (Kohen, 1999; Baudouin et al., 2002).

\section{AIR POLLUTANTS AND EFFECTS ON THE SKIN ULTRAVIOLET RADIATION}

The solar UVR consists of three spectral areas: UVA (320$400 \mathrm{~nm})$, UVB $(280-320 \mathrm{~nm})$, and UVC $(180-280 \mathrm{~nm})$. More than $95 \%$ of the solar UVR that reaches the earth's surface is UVA, $1-5 \%$ is UVB, whereas most UVC is absorbed by the $\mathrm{O}_{3}$ layer and oxygen in the atmosphere and is thus a very small source of adverse human health effects (Dessinioti et al., 2010). Small changes in stratospheric $\mathrm{O}_{3}$ increase the penetration of shorter ultraviolet wavelengths (UVA, UVB) at the ground level. The depletion of stratospheric $\mathrm{O}_{3}$ by chlorofluocarbons (CFCs) and other industrially produced $\mathrm{O}_{3}$ destructive substances presents a major problem in the environment and the human health (Schroeder et al., 2006). Despite the United Nations regulations, the stratospheric $\mathrm{O}_{3}$ layer is still thinner than that one century ago, while there is one $\mathrm{O}_{3}$ hole over the Antarctica and other openings over northern USA.

The effects of UVR on human skin differ depending on the wavelength. While UVA has been implicated in skin aging (photoaging), it has been linked, along with UVB, in the development of cutaneous immunosuppression and skin cancers such as malignant melanoma, basal cell carcinoma (BCC), and squamous cell carcinoma (SCC) (photocarcinogenesis). However, UVA and UVB damage DNA through different mechanisms. As the depth of penetration into the skin is dependent on the wavelength, UVB is largely absorbed by epidermal cellular components (proteins, DNA), while UVA radiation penetrates deeply into the basal layer of the epidermis and dermal fibroblasts. (Fisher et al., 1997; Dessinioti et al., 2010, 2011; Valacchi et al., 2012). Increasing evidence demonstrates that UVA in combination with common environmental pollutants, like PAHs significantly increases visible photodamage in skin (Burke and Wei, 2009).

UVR can induce gene alterations or immunosuppresion (Baudouin et al., 2002; Aubin, 2003; Amerio et al., 2009; Huang et al., 2009; Valacchi et al., 2012). Reports of the effects of $\mathrm{O}_{3}$ depletion noticed an increase in skin cancer in many countries associated with movements of the Antarctic "ozone hole" (Abarca et al., 2002; English et al., 2003), and a decrease of the age of skin cancer development (Al-Bareeq, 1995). For every 1\% decrease 
in $\mathrm{O}_{3}$ there is a $2 \%$ increase in UVB irradiance, and therefore a $2 \%$ increase in skin cancer is predicted (Goldsmith, 1996). The amount of average annual UV radiation has been traditionally correlated with the incidence of skin cancer (Armstrong and Kricker, 2001). Data from 28117 cutaneous melanoma cases reported during 1978-1993 to the EUROCARE group of registries reported a significant seasonal variation (with a summer peak) in melanoma incidence in most of the Western European registries, which was higher for Southern countries than for Northern countries (Boniol et al., 2005).

\section{POLYCYCLIC AROMATIC HYDROCARBONS (PAHS)}

PAHs are among the most widespread organic pollutants (Epstein et al., 1999; English et al., 2003). The main source of atmospheric PAH benzo[a]pyrene is residual wood burning (Burke and Wei, 2009). It is also found in automobile exhaust fumes (especially from diesel engines), and in all smoke resulting from the combustion of organic material (including cigarette smoke).

Skin pigmentation may also occur in the absence of UV radiation (Tschachler and Morizot, 2006) and PAHs induce melanocyte proliferation and thereby skin pigmentation (tanning) in mice (Vierkotter et al., 2010). PAHs are frequently bound to the surface of combustion-derived PM and absorbed on the surface of suspended PM in the air in urban areas (Menichini, 1992). PAHs are converted into quinines, redox-cycling chemicals that produce reactive oxygen species (Penning et al., 1999). Those pollutants can be adsorbed on the surface of PM, making it toxic. Long term-exposed skin to PM-bound PAHs either through hair follicle or transepidermal absorption (Lademann et al., 2004) may lead to oxidative stress and skin aging. Ambient particles (like soot) may be able to reach melanocytes, release surfacebound PAHs and/or directly affect the function of cutaneous cells (Vierkotter et al., 2010).

PAHs have been implicated in the development of skin cancer. Activated PAHs produce epoxides and diols, respectively, which bind to DNA and initiate cutaneous carcinogenesis (Kelfkens et al., 1991; Fernandez and Banerji, 1995; Hecht et al., 2001; Baudouin et al., 2002). The carcinogenic action of benzo $[a]$ pyrene was enhanced with the interaction of UVA (Kelfkens et al., 1991; Wei et al., 2003).

PAHs can lead to acneiform eruptions (Baudouin et al., 2002). 2,3,7,8-tetrachlorodibenzo-p-dioxin (TCDD) is the most potent member of the group of polyhalogenated aromatic hydrocarbons. This lipophilic compound has a long elimination half-life (5-10 years depending on exposure levels) and exerts pleiotropic biological effects by binding to the intracellular aromatic hydrocarbon receptor. It is formed in any burning, waste incineration, metal production, and fossil-fuel and wood combustion. Chloracne was described in the case of Victor Yushchenko's poisoning with TCDD in 2005 by Sorg et al. (2009). Chloracne is a systemic toxic disease caused by the exposure to chloracnegens (halogenated aromatic hydrocarbons) and is characterized by acneiform skin lesions such as comedones and cysts mainly on the face (outer sides of the eye and behind the ears) and neck. Other manifestations of chloracne include fatigue, liver dysfunction, neuropathy, arthritis (Tindall, 1985).

\section{VOLATILE ORGANIC COMPOUNDS (VOCS)}

Emission of VOCs originates from the use of organic solvents in paints, varnishes (e.g., aliphatic hydrocarbons, ethyl acetate, glycol ethers, methylene chloride, and acetone), vehicle refinishing products in repairing car paint, environmental tobacco smoke, stored fuels, exhaust from cars (e.g., benzene) and from emissions from industrial facilities (e.g., tetrachloroethene) (Dales et al., 2008; Kampa and Castanas, 2008; Okada et al., 2012). VOCs, with the presence of sunlight and NOx, cuase the formation of photochemical oxidant products mainly $\mathrm{O}_{3}$ - at ground level, also called summer photochemical smog (Schroeder et al., 2006). VOCs (ingestion of hexachlorobenzene) may induce precancerous skin lesions in rats (Michielsen et al., 1999).

Research in cultured keratinocytes showed that exposure to VOCs increases cytokines, which could then favor the development of inflammatory and/or allergic reaction as atopic dermatitis or eczema (Ushio et al., 1999).

\section{OXIDES}

Nitrogen oxides are emitted mainly from mobile and stationary combustion sources. They react with $\mathrm{O}_{3}$ or radicals in the atmosphere, forming $\mathrm{NO}_{2}$. Among $\mathrm{NOx}, \mathrm{NO}_{2}$ is known to cause oxidative damage resulting in the generation of free radicals that may oxidize amino acids in tissue proteins and initiate lipid peroxidation of polyunsaturated fatty acids (Eberlein-König et al., 1998).

Atmospheric sulfur dioxide $\left(\mathrm{SO}_{2}\right)$ can be formed from both anthropogenic (fuel combustion from power generation and industrial processes) and natural sources (volcanic activity, forest fires). CO is another pollutant, a product of incomplete combustion from mobile sources (Kampa and Castanas, 2008). Carbon monoxide acts on cell metabolism through hypoxic and nonhypoxic modes of action, resulting from its ability to bind to heme and alter its function and metabolism.

The prevalence of atopic dermatitis has been steadily increasing over the past few decades in Europe (Schultz-Larsen, 1993) and some studies point to a higher prevalence of atopic dermatitis in children who live in areas with high air pollution (Dotterud et al., 1994; Hayashi et al., 1995; Werfel and Kapp, 1998). Most air pollutants act as unspecific irritants as well as immunomodulators, leading to elevated levels of total serum IgE (Suzuki et al., 1989; Eberlein-König et al., 1998; Kim and Bernstein, 2009). An East-West German comparative study showed that the prevalence of atopic eczema was higher in East Germany (sulfurous type pollution), but also exhibited stronger association with atopic eczema with NOx exposure (indoor) and with inhabitance in close proximity to heavy traffic (Schäfer and Ring, 1997; Tombácz et al., 2009). The effects of traffic-related air pollutants and climatic factors on eczema prevalence in middle-school students was assessed in Taiwan and showed that flexural eczema was associated with traffic-related air pollutants, including NOx and carbon monoxide, with the auxiliary presence of the lowest monthly mean relative humidity (Lee et al., 2008). Also, an increased risk for flexural dermatitis in children exposed to high levels of trafficrelated air pollution has been reported (Annesi-Maesano et al., 2007). 


\section{PARTICULATE MATTER (PM)}

Air pollutants, consisting of complex and varying mixtures of different size and composition particles suspended in the air was called PM. Factories, power plants, refuse incinerators, automobile, construction activities, fires and natural windblown dust are some of the main sources of PM (Poschl, 2005; Lazaridis et al., 2008; Dagouassat et al., 2012). Their major components are metals, organic compounds, material of biologic origin, ions, reactive gases, and the particle carbon core (Kampa and Castanas, 2008).

Particles in the nanosize range, especially those from traffic sources, are considered among the most harmful components of ambient PM, since their particular physical properties make them highly reactive toward biological surfaces and structures and induce oxidative stress in human skin (Vierkotter et al., 2010). The generation of oxidative stress by PM contributes to extrinsic skin aging (Donaldson et al., 2005; Vierkotter et al., 2010). Another study showed a significant correlation between PM pollution exposure (traffic particle and soot) and extrinsic skin aging signs, such as pigment spots on face, nasolabial folds, and wrinkles (Vierkotter et al., 2010).

\section{OZONE}

$\mathrm{O}_{3}$ exists in the stratosphere and in troposphere (Baudouin et al., 2002; Madronich et al., 2011). Normally, $\mathrm{O}_{3}$ is found in low concentrations at ground-level, originating from the stratospheric $\mathrm{O}_{3}$ and hydrocarbons which are released by plants and soil. However, $\mathrm{O}_{3}$ may be formed as a by-product of certain human activities, with the interaction of sunlight (UVR), hydrocarbons, VOCs and $\mathrm{NOx}$, representing a major active component of the pro-oxidant smog (Baudouin et al., 2002; Schroeder et al., 2006; Madronich et al., 2011). The actions of $\mathrm{O}_{3}$ could be amplified in the presence of other air pollutants, where concomitant exposure to UV irradiation and $\mathrm{O}_{3}$ could reveal synergistic oxidative stress effects in skin (Baudouin et al., 2002; Burke and Wei, 2009).

Experimental evidence shows that $\mathrm{O}_{3}$ can induce damage in the epidermis of murine skin, reduce the level of antioxidants such as a-topopherol (vitamin E) and ascorbic acid (vitamin C) and increase malondialdehyde (MDA) a lipid peroxidation product (Thiele et al., 1997a,b; Weber et al., 1999; Schroeder et al., 2006). These effects lead to barrier perturbations, the production of lipid ozonation products and inflammation (Podda and Fuchs, 2004; Schroeder et al., 2006; Valacchi et al., 2012). The first target of $\mathrm{O}_{3}$ is the stratum corneum that contains a high level of unsaturated fatty acids and lipids (Packer and Valacchi, 2002; He et al., 2006), with the generation of ROS. $\mathrm{O}_{3}$ stimulation results in disturbed activity of matrix metalloproteinases (MMPs), responsible for the degradation of extracellular matrix components such as collagen and elastin, implicated in extrinsic skin aging (Rittié and Fisher, 2002; Schroeder et al., 2006). Tropospheric $\mathrm{O}_{3}$ exposure has been associated with urticaria, eczema, and contact dermatitis, in a study showing the cutaneous effects of $\mathrm{O}_{3}$ by collecting data from almost 70,000 patients (Xu et al., 2011).

On the other hand, pollutants [i.e., $\mathrm{O}_{3}$, nitrogen dioxide $\left(\mathrm{NO}_{2}\right)$, and $\left.\mathrm{SO}_{2}\right]$ and scattering particulates (clouds and soot) in the troposphere reduce the effects of shorter wavelength UVR more than longer wavelength (Madronich et al., 2011). Large reductions in UV irradiance have been observed in polluted, urban areas when compared to pristine locations (Kazadzis et al., 2009; McKenzie et al., 2011). Significant reductions in UVB radiation can occur with naturally occurring pollutants, such as dust, volcanic ash, and wild fire aerosols (Jansen et al., 2013). In addition, a study in the co-existence of $\mathrm{O}_{3}$ with other air pollutants, like PM with aerodynamic diameter of $10 \mathrm{~lm}$ or less (PM10), $\mathrm{SO}_{2}$, and $\mathrm{NO}_{2}$, didn't show any correlation with the increase in skin disorders (Xu et al., 2011).

\section{CIGARETTE SMOKE}

Cigarette smoke is a highly complex aerosol composed of thousands of chemical substances, including ROS, reactive nitrogen species and electrophilic aldehydes (Dube and Green, 1982; Church and Pryor, 1985; Valacchi et al., 2012). Environmental cigarette smoke contains carcinogens, such as benzo [a] pyrene and 4-(methylnitrosoamino)- 1-(3-pyridyl)-1-butanone (NNK), and also a large amount of oxygen radical forming substances, such as catechol, known to interact with the skin (Gottipati et al., 2008). Reactive oxidants and free radicals from cigarette smoke are associated with oxidative stress or secondary oxidative events, such as lipid peroxidation (Pryor et al., 1983, 1984; Church and Pryor, 1985; Chow, 1993; Boyd et al., 2002; Dietrich et al., 2003). Chemical substances from cigarette smoke activate transepidermal water loss, degeneration of connective tissue in the skin and increase of matrix metalloproteinases (MMP-1, MMP-3) (Jorgensen et al., 1998; Wolf et al., 1998; Yin et al., 2000; Just et al., 2007; Valacchi et al., 2012).

Smoking is correlated with deeper periorbital wrinkling (Solly, 1856; Daniell, 1971; Freiman et al., 2004). Premature facial skin aging in smokers, with a characteristic pattern of wrinkling and orange-purple skin discoloration, was defined as smoker's face (O'Hare et al., 1999). Heavy cigarette smokers were 4.7 times more likely to have facial wrinkles than non-smokers, independent of sun exposure (Kadunce et al., 1991; Freiman et al., 2004), although the combination of smoking and sun exposure may have a synergistic effect on skin aging.

Cigarette smoke is associated with psoriasis (Kavli et al., 1985; Mills et al., 1992; Gupta et al., 1996; Naldi et al., 1999; Armstrong et al., 2011). A recent meta-analysis of prevalence studies included a total of 146,934 psoriasis patients and reported an association between psoriasis and current or former smoking (pooled OR: 1.78, 95\%|CI: 1.52-2.06, and pooled OR: 1.62 , 95\% CI: 1.33-1.99, respectively), concluding that smoking is an independent risk factor for the development of psoriasis (Armstrong et al., 2014). The effect of smoking could be mediated by the ROS and in particular by the disturbed balance of oxidants and antioxidants, indicated with low levels of vitamin $\mathrm{C}$ and glutathione, and high levels of superoxide dismutase and malonaldehyde in cutaneous tissues (Isik et al., 2007; Armstrong et al., 2011; Valacchi et al., 2012).

A higher prevalence of acne among smokers and a correlation between the severity of acne and the number of smoked cigarettes has been shown (Schäfer et al., 2001). A study of 226 post-adolescent women with acne reported smoking in $66.3 \%$ of patients and there was an association of smoking with comedonal post-adolescent acne compared to the papulopustular form $(p<0.0001)$. The authors reported that although the correlation between acne and smoking is still controversial, there is 
a hyperkeratizing effect of cigarette-smoke compounds, and in particular of nicotine. Nicotine is an agonist of acetylcholine (ACh) and may induce comedogenesis (the formation of comedones) via the stimulation of ACh nicotinic receptor on epidermal keratinocytes (Capitanio et al., 2010).

Tobacco smoking has been associated with cutaneous SCC, (Leonardi-Bee et al., 2012) and keratoacanthoma, (El-Hakim and Uthman, 1999), while the link between smoking and BCC remains controversial (van Dam et al., 1999; Wojno, 1999; Corona et al., 2001; De Hertog et al., 2001; Boyd et al., 2002; Milan et al., 2003; Leonardi-Bee et al., 2012; Valacchi et al., 2012).

\section{CONCLUSIONS}

Major air pollutants with effects on the skin include the solar UVR, PAHs, VOCs, $\mathrm{NOx}, \mathrm{PM}, \mathrm{O}_{3}$, and cigarette smoke. Considerable effects mediated by air pollutants on the human skin may contribute to skin aging, atopic dermatitis, skin cancer, psoriasis, and acne.

Oxides have been associated with increased prevalence of atopic dermatitis as well as exacerbations of the disease in children. VOCs, with the presence of sunlight and NOx, cause the formation of photochemical oxidant products -mainly $\mathrm{O}_{3}$ - at ground level, also called summer photochemical smog. Exposure to $\mathrm{O}_{3}$ has been associated with urticaria, eczema, contact dermatitis, and other nonspecific eruptions. Exposure to PM contributes to extrinsic skin aging (wrinkles, pigmented macules or spots). Cigarette smoking has been associated with skin aging (wrinkles, skin dryness, skin dyschromias), and the combination of smoking and sun exposure may have a synergistic effect on skin aging. Furthermore, it has been associated with skin cancer (SCC, BCC), psoriasis and acne vulgaris.

On the other hand, pollutants (i.e., $\mathrm{O}_{3}, \mathrm{NO}_{2}$, and $\mathrm{SO}_{2}$ ) and scattering particulates (clouds and soot) in the troposphere reduce the effects of shorter wavelength UVR and significant reductions in UV irradiance have been observed in polluted, urban areas.

\section{REFERENCES}

Abarca, J. F., Casiccia, C. C., and Zamorano, F. D. (2002). Increase in sunburns and photosensitivity disorders at the edge of the Antarctic ozone hole, southern Chile, 1986-2000. J. Am. Acad. Dermatol. 46, 193-199. doi: 10.1067/mjd.2002.118556

Adelman, R., Saul, R. L., and Ames, B. N. (1988). Oxidative damage to DNA: relation to species metabolic rate and life span. Proc. Natl. Acad. Sci. U.S.A. 85, 2706-2708. doi: 10.1073/pnas.85.8.2706

Al-Bareeq, J. M. (1995). Environmental pollution and health. Bahrain Med. Bull. 17, 1-5. Available online at: http://www.bahrainmedicalbul letin.com/issue_dec1995.htm

Amerio, P., Carbone, A., Auriemma, M., Varrati, S., and Tulli, A. (2009). UV induced skin immunosuppression. Antiinflamm. Antiallergy Agents Med. Chem. 8, 3-13. doi: $10.2174 / 187152309787580775$

Ames, B. N., Gold, L. S., and Willett, W. C. (1995). The cause and prevention of cancer. Proc. Natl. Acad. Sci. U.S.A. 92, 5258-5265. doi: 10.1073/pnas.92.12.5258

Annesi-Maesano, I., Moreau, D., Caillaud, D., Lavaud, F., Le Moullec, Y., Taytard, A., et al. (2007). Residential proximity fine particles related to allergic sensitisation and asthma in primary school children. Respir. Med. 101, 1721-1729. doi: 10.1016/j.rmed.2007.02.022

Armstrong, A. W., Armstrong, E. J., Fuller, E. N., Sockolov, M. E., and Voyles, S. V. (2011). Smoking and pathogenesis of psoriasis: a review of oxidative, inflammatory and genetic mechanisms. Br. J. Dermatol. 165, 1162-1168. doi: $10.1111 / j .1365-2133.2011 .10526 . x$
Armstrong, A. W., Harskamp, C. T., Dhillon, J. S., and Armstrong, E. J. (2014). Psoriasis and smoking: a systematic review and meta-analysis. $\mathrm{Br}$. J. Dermatol. 170, 304-314. doi: 10.1111/bjd.12670

Armstrong, B. K., and Kricker, A. (2001). Epidemiology of skin cancer. Photochem. Photobiol. 63, 8-18. doi: 10.1016/S1011-1344(01)00198-1

Aubin, F. (2003). Mechanisms involved in ultraviolet light-induced immunosuppression. Eur. J. Dermatol. 13, 515-523. Available online at: http://www.europeanjournalofdermatology.com/archives/sommaire.phtml?cle parution $=846$

Baudouin, C., Charveron, M., Tarroux, R., and Gall, Y. (2002). Environmental pollutants and skin cancer. Cell Biol. Toxicol. 18, 341-348. doi: 10.1023/A:1019540316060

Boniol, M., De Vries, E., Coebergh, J. W., and Dore, J. F. (2005). Seasonal variation in the occurrence of cutaneous melanoma in Europe: influence of latitude. An analysis using the EUROCARE group of registries. Eur. J. Cancer 41, 126-132. doi: 10.1016/j.ejca.2004.09.011

Boyd, A. S., Shyr, Y., and King, L. E. Jr. (2002). Basal cell carcinoma in young women: an evaluation of the association of tanning bed use and smoking. J. Am. Acad. Dermatol. 46, 706-709. doi: 10.1067/mjd.2002.120467

Burke, K. E., and Wei, H. (2009). Synergistic damage by UVA radiation and pollutants. Toxicol. Ind. Health. 25, 219-224. doi: 10.1177/074823370 9106067

Capitanio, B., Sinagra, J. L., Bordignon, V., Cordiali, F. P., Picardo, M., and Zouboulis, C. C. (2010). Underestimated clinical features of postadolescent acne. J. Am. Acad. Dermatol. 63, 782-788. doi: 10.1016/j.jaad. 2009.11.021

Chow, C. K. (1993). Cigarette smoking and oxidative damage in the lung. Ann. N.Y. Acad. Sci. 686, 289-298. doi: 10.1111/j.1749-6632.1993.tb39189.x

Church, D. F., and Pryor, W. A. (1985). Free-radical chemistry of cigarette smoke and its toxicological implications. Environ. Health Perspect. 64, 111-126. doi: 10.1289/ehp.8564111

Corona, R., Dogliotti, E., D’Errico, M., Sera, F., Iavarone, I., Baliva, G., et al. (2001). Risk factors for basal cell carcinoma in a Mediterranean population: role of recreational sun exposure early in life. Arch. Dermatol. 137, 1162-1168. doi: 10.1001/archderm.137.9.1162

Dagouassat, M., Lanone, S., and Boczkowski, J. (2012). Interaction of matrix metalloproteinases with pulmonary pollutants. Eur. Respir. J. 39, 1021-1032. doi: $10.1183 / 09031936.00195811$

Dales, R., Liu, L., Wheeler, A. J., and Gilbert, N. L. (2008). Quality of indoor residential air and health. CMAJ 179, 147-152. doi: 10.1503/cmaj.070359

Daniell, H. W. (1971). Smoker's wrinkles. A study in the epidemiology of "crow's feet.” Ann. Intern. Med. 75, 873-880. doi: 10.7326/0003-4819-75-6-873

De Hertog, S. A., Wensveen, C. A., Bastiaens, M. T., Kielich, C. J., Berkhout, M. J., Westendorp, R. G., et al. (2001). Relation between smoking and skin cancer. J. Clin. Oncol. 19, 231-238. Available online at: http://jco.ascopubs.org/content/19/1/231.abstract

Dessinioti, C., Antoniou, C., Katsambas, A., and Stratigos, A. J. (2010). Basal cell carcinoma: What's new under the sun. Photochem. Photobiol. 86, 481-491. doi: 10.1111/j.1751-1097.2010.00735.x

Dessinioti, C., Tzannis, K., Sypsa, V., Nikolaou, V., Kypreou, K., Antoniou, C., et al. (2011). Epidemiologic risk factors of basal cell carcinoma development and age at onset in a Southern European population from Greece. Exp. Dermatol. 20, 622-626. doi: 10.1111/j.1600-0625.2011.01275.x

Dietrich, M., Block, G., Benowitz, N. L., Morrow, J. D., Hudes, M., Jacob, P. 3rd., et al. (2003). Vitamin C supplementation decreases oxidative stress biomarker F2-isoprostanes in plasma of nonsmokers exposed to environmental tobacco smoke. Nutr. Cancer. 45, 176-184. doi: 10.1207/S15327914NC4502_06

Donaldson, K., Tran, L., Jimenez, L. A., Duffin, R., Newby, D. E., Mills, N., et al. (2005). Combustion-derived nanoparticles: a review of their toxicology following inhalation exposure. Part. Fibre Toxicol. 2:10. doi: 10.1186/1743-8977-2-10

Dotterud, L. K., Kvammen, B., BoUe, R., and Balk, E. S. (1994). A survey of atopic diseases among schoolchildren in Sor-Varanger community. Possible effects of subarctic climate and industrial pollution from Russia. Acta Derm. Venereol. 74,124-128.

Dube, M. F., and Green, C. R. (1982). Methods of collection of smoke for analytical purposes. Recent Adv. Tobacco Sci. 8, 42-102.

Eberlein-König, B., Przybilla, B., Kûhnl, P., Pechak, J., Gebefügi, I., Kleinschmidt, J., et al. (1998). Influence of airborne nitrogen dioxide or formaldehyde on parameters of skin function and cellular activation in patients with atopic 
eczema and control subjects. J. Allergy Clin. Immunol. 101, 141-143. doi: 10.1016/S0091-6749(98)70212-X

El-Hakim, I. E., and Uthman, M. A. (1999). Squamous cell carcinoma and keratoacanthoma of the lower lip associated with "Goza" and "Shisha" smoking. Int. J. Dermatol. 38, 108-110. doi: 10.1046/j.1365-4362.1999.00448.x

English, J. S. C., Dawe, R. S., and Ferguson, J. (2003). Environmental effects and skin disease. Br. Med. Bull. 68, 129-142. doi: 10.1093/bmb/ldg026

Epstein, J. H., Ormsby, A., and Adams, R. M. (1999). "Occupational skin cancer," in Occupational Skin Disease, 3rd edn., ed R. M. Adams (Philadelphia, PA: W. B. Saunders Company), 142-164.

Fernandez, A. O., and Banerji, A. P. (1995). Inhibition of benzopyreneinduced forestomach tumors by field bean protease inhibitors(s). Carcinogenesis 16, 1843-1846. doi: 10.1093/carcin/16.8.1843

Fisher, G. J., Wang, Z. Q., Datta, S. C., Varani, J., Kang, S., and Voorhees, J. J. (1997). Pathophysiology of premature skin aging induced by ultraviolet light. N. Engl. J. Med. 337, 1419-1428. doi: 10.1056/NEJM199711133372003

Freiman, A., Bird, G., Metelitsa, A. I., Barankin, B., and Lauzon, G. J. (2004). Cutaneous effects of smoking. J. Cutan. Med. Surg. 8, 415-423. doi: 10.1007/s10227-005-0020-8

Gaboran, F., Moliere, P., Maquis, I., Moysa, A., Geze, M., and Dubertret, L. (1993). Membrane damage induced in cultured human skin fibroblast by UVA irradiation. Photochem. Photobiol. 58, 515-520. doi: 10.1111/j.17511097.1993.tb04924.x

Goldsmith, L. A. (1996). Skin effects of air pollution. Otolaryngol. Head Neck Surg. 14, 217-219. doi: 10.1016/S0194-5998(96)70169-9

Gottipati, K. R., Poulsen, H., and Starcher, B. (2008). Passive cigarette smoke exposure inhibits ultraviolet light B-induced skin tumors in SKH-1 hairless mice by blocking the nuclear factor kappa B signalling pathway. Exp. Dermatol. 17, 780-787. doi: 10.1111/j.1600-0625.2007.00685.x

Gupta, M. A., Gupta, A. K., and Watteel, G. N. (1996). Cigarette smoking in men may be a risk factor for increased severity of psoriasis of the extremities. Br. J. Dermatol. 135, 859-860. doi: 10.1111/j.1365-2133.1996.tb03909.x

Halliwell, B., and Gutteridge, J. M. C. (1989). Free Radical in Biology and Medicine. Oxford: Clarendon Press; Oxford Univ Press, 160-165.

Hayashi, T., Kawakami, N., Kondo, N., Agata, H., Fukutomi, O., Shimizu, H., et al. (1995). Prevalence of and risk factors for allergic diseases: comparison of two cities in Japan. Ann. Allergy Asthma Immunol. 75, 525-529.

He, Q. C., Tavakkol, A., Wietecha, K., Begum-Gafur, R., Ansari, S. A., and Polefka, T. (2006). Effects of environmentally realistic levels of ozone on stratum corneum function. Int. J. Cosmet. Sci. 28, 349-357. doi: 10.1111/j.14672494.2006.00347.x

Hecht, S. S., Kenney, P. M., Wang, M., and Upadhyaya, P. (2001). Doseresponse study of myo-inositol as an inhibitor of lung tumorigenesis induced in A/J mice by benzo[a]pyrene and 4-(methylnitrosamino)-1-(3pyridyl)-1-butanone. Cancer. Lett. 167, 1-6. doi: 10.1016/S0304-3835(01) 00454-2

Huang, X. X., Bernerd, F., and Halliday, G. M. (2009). Ultraviolet A within sunlight induces mutations in the epidermal basal layer of engineered human skin. Am. J. Pathol. 174, 1534-1543. doi: 10.2353/ajpath.2009.080318

Isik, B., Ceylan A., and Isik, R. (2007). Oxidative stress in smokers and nonsmokers. Inhal. Toxicol. 19, 767-769. doi: 10.1080/08958370701401418

Jansen, R., Wang S. Q., Burnett, M., Osterwalder, U., and Lim, H. W. (2013). Photoprotection: part I. Photoprotection by naturally occurring, physical, and systemic agents. J. Am. Acad. Dermatol. 69, 853.e1-853.e12. doi: 10.1016/j.jaad.2013.08.021

Jorgensen, L. N. K., Kallehave, F., Christensen, E., Siana, J. E., and Gottrup, F. (1998). Less collagen production in smokers. Surgery 123, 450-455. doi: 10.1016/S0039-6060(98)70167-9

Just, M., Ribera, M., Monsó, E., Lorenzo, J. C., and Ferrándiz, C. (2007). Effect of smoking on skin elastic fibres: morphometric and immunohistochemical analysis. Br. J. Dermatol. 156, 85-91. doi: 10.1111/j.1365-2133.2006.07575.x

Kadunce, D. P., Burr, R., Gress, R., Kanner, R., Lyon, J. L., and Zone, J. J. (1991). Cigarette smoking: risk factor for premature facial wrinkling. Ann. Intern. Med. 114, 840- 844. doi: 10.7326/0003-4819-114-10-840

Kampa, M., and Castanas, E. (2008). Human health effects of air pollution. Environ. Pollut. 151, 362-367. doi: 10.1016/j.envpol.2007.06.012

Karten, B., Beisiegel, U., Gercken, G., and Konstusk, A. (1988). Mechanism of lipid peroxidation in human blood plasma (a kinetic approach). Chem. Phys. Lipid 88, 83-96. doi: 10.1016/S0009-3084(97)00038-8
Katsouyanni, K. (2003). Ambient air pollution and health. Br. Med. Bull. 68, 143-156. doi: 10.1093/bmb/ldg028

Kavli, G., Førde, O. H., Arnesen, E., and Stenvold, S. E. (1985). Psoriasis: familial predisposition and environmental factors. Br. Med. J. 291, 999-1000. doi: 10.1136/bmj.291.6501.999

Kazadzis, S., Bais, A., Balis, D., Kouremeti, N., Zempila, M., Arola, A., et al. (2009). Spatial and temporal UV irradiance and aerosol variability within the area of an OMI satellite pixel. Atmos. Chem. Phys. 9, 4593-4601. doi: 10.5194/acp-9-45932009

Kelfkens, G., de Gruijl, F. R., and van der Leun, J. C. (1991). Tumorigenesis by shortwave ultraviolet A: papillomas versus squamous cell carcinomas. Carcinogen 12, 1377-1382. doi: 10.1093/carcin/12.8.1377

Kim, H., and Bernstein, J. A. (2009). Air pollution and allergic disease. Curr. Allergy Asthma Rep. 9, 128-133. doi: 10.1007/s11882-009-0019-0

Kohen, R. (1999). Skin antioxidants: their role in aging and in oxidative stressnew approaches for their evaluation. Biomed. Pharmacother. 53, 181-192. doi: 10.1016/S0753-3322(99)80087-0

Lademann, J., Schaefer, H., Otberg, N., Teichmann, A., Blume-Peytavi, U., and Sterry, W. (2004). Penetration of microparticles into human skin. Hautarzt 55, 1117-1119. doi: 10.1007/s00105-004-0841-1

Lazaridis, M., Latos, M., Aleksandropoulou, V., Hov, Ø., Papayannis, A., and Tørseth, K. (2008). Contribution of forest fire emissions to atmospheric pollution in Greece. Air Qual. Atmos. Health 1, 143-158. doi: 10.1007/s11869-0080020-0

Lee, Y. L., Su, H. J., Sheu, H. M., Yu, H. S., and Guo, Y. L. (2008). Traffic-related air pollution, climate, and prevalence of eczema in taiwanese school children. J. Invest. Dermatol. 128, 2412-2420. doi: 10.1038/jid.2008.110

Leonardi-Bee, J., Ellison, T., and Bath-Hextall, F. (2012). Smoking and the risk of nonmelanoma skin cancer: systematic review and meta-analysis. Arch. Dermatol. 148, 939-946. doi: 10.1001/archdermatol.2012.1374

Madronich, S., Wagner, M., and Groth, P. (2011). Influence of tropospheric ozone control on exposure to ultraviolet radiation at the surface. Environ. Sci. Technol. 45, 6919-6923. doi: 10.1021/es200701q

McKenzie, R. L., Aucamp, P. J., Bais, A.F., Björn, L.O., Ilyas, M., and Madronich, S. (2011). Ozone depletion and climate change: impacts on UV radiation. Photochem. Photobiol. Sci. 10, 182-198. doi: 10.1039/c0pp90034f

Menichini, E. (1992). Urban air pollution by polycyclic aromatic hydrocarbons: levels and sources of variability. Sci. Total Environ. 116, 109-135. doi: 10.1016/0048-9697(92)90368-3

Menzel, D. B. (1994). The toxicity of air pollution in experimental animals and humans: the role of oxidative stress. Toxicol. Lett. 72, 269-277. doi: 10.1016/0378-4274(94)90038-8

Michielsen, C. C., van Loveren, H., and Vos, J. G. (1999). The role of the immune system in hexachlorobenzene-induced toxicity. Environ. Health Perspect. 107, 783-792. doi: 10.1289/ehp.99107s5783

Milan, T., Verkasalo, P. K., Kaprio, J., and Koskenvuo, M. (2003). Lifestyle differences in twin pairs discordant for basal cell carcinoma of the skin. Br. J. Dermatol. 149, 115-123. doi: 10.1046/j.1365-2133.2003.05352.x

Mills, C. M., Srivastava, E. D., Harvey, I. M., Swift, G. L., Newcombe, R. G., Holt, P. J. A., et al. (1992). Smoking habits in psoriasis: a case control study. Br. J. Dermatol. 271, 18-21. doi: 10.1111/j.1365-2133.1992.tb14818.x

Naldi, L., Peli L., and Parazzini F. (1999). Association of early stage psoriasis with smoking and male alcohol consumption: evidence from an Italian casecontrol study. Arch. Dermatol. 135, 1479-1484. doi: 10.1001/archderm.135. 12.1479

O’Hare, P. M., Fleischer, A. B. Jr., D’Agostino, R. B. Jr., Feldman, S. R., Hinds, M. A., Rassette, S. A., et al. (1999). Tobacco smoking contributes little to facial wrinkling. J. Bur. Acad. Dermatol. Venereol. 122,133-139. doi: 10.1111/j.14683083.1999.tb01003.x

Okada, Y., Nakagoshi, A., Tsurukawa, M., Matsumura, C., Eiho, J., and Nakano, T. (2012). Environmental risk assessment and concentration trend of atmospheric volatile organic compounds in Hyogo Prefecture, Japan. Environ. Sci. Pollut. Res. Int. 19, 201-213. doi: 10.1007/s11356-011-0550-0

Packer, L., and Valacchi, G. (2002). Antioxidants and the response of skin to oxidative stress: vitamin E as a key indicator. Skin Pharmacol. Appl. Skin Physiol. 15, 282-290. doi: 10.1159/000064531

Penning, T. M., Burcynski, M. E., Hung, C. F., McCoull, K. D., Palackal, N. T., and Tsuruda, L. S. (1999). Dihydrodiol dehydrogenase and polycyclic aromatic hydrocarbon activation: generation of reactive and 
redox active o-quinones. Chem. Res. Toxicol. 12, 1-18. doi: 10.1021/ tx980143n

Podda, M., and Fuchs, J. (2004). Influence of environmental polluting ozone on the skin. Hautarzt 55, 1120-1124. doi: 10.1007/s00105-004-0842-0

Poschl, U. (2005). Atmospheric aerosols: composition, transformation, climate and health effects. Angew. Chem. Int. Edn. 44, 7520-7540. doi: 10.1002/anie.200501122

Pryor, W. A., Dooley, M. M., and Church, D. F. (1984). Inactivation of human alpha-1-proteinase inhibitor by gas-phase cigarette smoke. Biochem. Biophys. Res. Commun. 122, 676-681. doi: 10.1016/S0006-291X(84) 80086-8

Pryor, W. A., Prier, D. G., and Church, D. F. (1983). Electron-spin resonance study of mainstream and sidestream cigarette smoke: nature of the free radicals in gas-phase smoke and in cigarette tar. Environ. Health Perspect. 47, 345-355. doi: 10.1289/ehp. 8347345

Rittié, L., and Fisher, G.J. (2002). UV-light-induced signal cascades and skin aging. Ageing Res. Rev. 1,705-720. doi: 10.1016/S1568-1637(02)00024-7

Schäfer, T., Nienhaus, A., Vieluf, D., Berger, J., and Ring, J. (2001). Epidemiology of acne in the general population: the risk of smoking. Br. J. Dermatol. 1451, 100-104. doi: 10.1046/j.1365-2133.2001.04290.x

Schäfer, T., and Ring, J. (1997). Epidemiology of allergic diseases. Allergy 52, 14-22. doi: 10.1111/j.1398-9995.1997.tb04864.x

Schroeder, P., Schieke, S. M., and Morita, A. (2006). "Premature skin aging by infrared radiation, tobacco smoke and Ozone," in Skin Aging, eds B. A. Gilchrest and J. Krutmann (Berlin; Heidelberg: Springer), 45-55. doi: 10.1007/3-54032953-6_5

Schultz-Larsen, F. (1993). Atopic dermatitis. A genetic-epidemiologic study in a population-based twin sample. J. Am. Acad. Dermatol. 28, 719-723. doi: 10.1016/0190-9622(93)70099-F

Solly, S. (1856). Clinical lectures on paralysis. Lancet 68, 641-643. doi: 10.1016/S0140-6736(02)60376-9

Sorg, O., Zennegg, M., Schmid, P., Fedosyuk, R., Valikhnovskyi, R., Gaide, O., et al. (2009). 2,3,7,8-tetrachlorodibenzo-p-dioxin (TCDD) poisoning in Victor Yushchenko: identification and measurement of TCDD metabolites. Lancet 374, 1179-1185. doi: 10.1016/S0140-6736(09)60912-0

Stadtman, E. R. (1992). Protein oxidation and aging. Science 257, 1220-1224. doi: 10.1126/science. 1355616

Suzuki, S., Takafuji, S., and Miyamoto T. (1989). Particle air pollutants as enhancers of IgE production. Allergy Clin. Immunol. News 1, 76.

Thiele, J. J., Podda, M., and Packer, L. (1997b). Tropospheric ozone: an emerging environmental stress to skin. Biol. Chem. 378, 1299-1305.

Thiele, J. J., Traber, M. G., Tsang, K., Cross, C. E., and Packer, L. (1997a). In vivo exposure to ozone depletes vitamins $\mathrm{C}$ and $\mathrm{E}$ and induces lipid peroxidation in epidermal layers of murine skin. Free Radic. Biol. Med. 23, 385-391. doi: 10.1016/S0891-5849(96)00617-X

Tindall, J. P. (1985). Chloracne and chloracnegens. J. Am. Acad. Dermatol. 13, 539-558. doi: 10.1016/S0190-9622(85)70196-X

Tombácz, S. Z., Eötvös, T., and Makra, L. (2009). Environmental and social conditions of asthma and rhinitis. Acta Climatol. Chorol. 42-43, 159-173. Available online at: http://www2.sci.u-szeged.hu/eghajlattan/akta09/ ACTA_2009_P16.pdf

Tschachler, E., and Morizot, F. (2006). "Ethnic differences in skin aging," in Skin Aging, eds B. Gilchrest and J. Krutmann (New York, NY: Springer-Verlag), 23-30. doi: 10.1007/3-540-32953-6_3
Ushio, H., Nohara, K., and Fujimaki, H. (1999). Effect of environmental pollutants on the production of pro-inflammatory cytokines by normal human dermal keratinocytes. Toxicol. Lett. 105, 17-24. doi: 10.1016/S0378-4274(98)00379-8

Valacchi, G., Sticozzi, C., Pecorelli, A., Cervellati, F., Cervellati, C., and Maioli, E. (2012). Cutaneous responses to environmental stressors. Ann. N.Y. Acad. Sci. 1271, 75-81. doi: 10.1111/j.1749-6632.2012.06724.x

Valko, M., Leibfritz, D., Moncol, J., Cronin, M. T., Mazur, M., and Telser, J. (2006). Free radicals and antioxidants in normal physiological functions and human disease. Int. J. Biochem. Cell Biol. 39, 44-84. doi: 10.1016/j.biocel.2006. 07.001

van Dam, R. M., Huang, Z., Rimm, E. B., Weinstock, M. A., Spiegelman, D., Colditz, G. A., et al. (1999). Risk factors for basal cell carcinoma of the skin in men: results from the health professionals follow-up study. Am. J. Epidemiol. 150, 459-468. doi: 10.1093/oxfordjournals.aje.a010034

Vierkotter, A., Schikowski, T., Ranft, U., Sugiri, D., Matsui, M., Kramer, U., et al. (2010). Airborne particle exposure and extrinsic skin aging. J. Invest. Dermatol. 130, 2719-2726. doi: 10.1038/jid.2010.204

Weber, S. U., Thiele, J. J., Cross, C. E., and Packer, L. (1999). Vitamin C, uric acid, and glutathione gradients in murine stratum corneum and their susceptibility to ozone exposure. J. Invest. Dermatol. 113, 1128-1132. doi: 10.1046/j.15231747.1999.00789.x

Wei, H., Saladi, R., and Wang, Y. (2003). Synergistic carcinogenesis of chemical carcinogens and long wave-length UVA radiation. Trends Photochem. Photobiol. 10, 31-45. Available online at: http://www.researchtrends.net/tia/title.asp?id=15

Werfel, T., and Kapp, A. (1998). Environmental and other major provocation factors in atopic dermatitis. Allergy 53, 731-739. doi: 10.1111/j.13989995.1998.tb03968.x

Wojno, T. H. (1999). The association between cigarette smoking and basal cell carcinoma of the eyelids in women. Ophthalmic Plast. Rec. 15, 390-392. doi: 10.1097/00002341-199911000-00004

Wolf, R., Wolf, D., and Ruocco, V. (1998). Smoking and the skin, radically speaking. Clin. Dermatol. 16, 633-639. doi: 10.1016/S0738-081X(98)00049-2

Xu, F., Yan, S., Wu, M., Li, F., Xu, X., Song, W., et al. (2011). Ambient ozone pollution as a risk factor for skin disorders. Br. J. Dermatol. 165, 224-225. doi: 10.1111/j.1365-2133.2011.10349.x

Yin, L., Morita, A., and Tsuji, T. (2000). Alterations of extracellular matrix induced by tobacco smoke extract. Arch. Dermatol. Res. 292, 188-194. doi: $10.1007 / \mathrm{s} 004030050476$

Conflict of Interest Statement: The authors declare that the research was conducted in the absence of any commercial or financial relationships that could be construed as a potential conflict of interest.

Received: 01 April 2014; accepted: 24 April 2014; published online: 15 May 2014. Citation: Drakaki E, Dessinioti C and Antoniou CV (2014) Air pollution and the skin. Front. Environ. Sci. 2:11. doi: 10.3389/fenvs.2014.00011

This article was submitted to Air Pollution, a section of the journal Frontiers in Environmental Science.

Copyright (c) 2014 Drakaki, Dessinioti and Antoniou. This is an open-access article distributed under the terms of the Creative Commons Attribution License (CC BY). The use, distribution or reproduction in other forums is permitted, provided the original author(s) or licensor are credited and that the original publication in this journal is cited, in accordance with accepted academic practice. No use, distribution or reproduction is permitted which does not comply with these terms. 